\title{
Er det nødvendigt at sige op - for at lytte til borgerne?
}

\author{
Af Annemette Digmann*)
}

\section{Resumé:}

Denne artikel kan læses i forlængelse af en samskabelsescase, der blev bragt i SIS i 2018. I eksemplet havde to pædagoger valgt at sige deres kommunale job op, for at få lov til at lytte til borgernes ønsker og behov. Efterfølgende ønskede kommunen at lære af de eksterne erfaringer med at samskabe med borgere. I denne artikel dokumenterer jeg, hvordan en kommunal institution forsøger at inddrage borgernes ønsker i arbejdet, og hvorfor det er så vanskeligt, at det mere eller mindre er dømt til at mislykkes. Spørgsmålet er, om samskabelsesdagsordenen bare er endnu et smart slagord, der måske allerede er på vej mod glemslen, eller om der et eller andet sted findes en vilje til reelt at inddrage borgerne i udviklingen af velfærdsydelserne? For de organisationer, der reelt vil samskabelse, slutter artiklen med en række anbefalinger til dét arbejde.

Emneord: Aktionsforskning; samskabelse; partnerskabsledelse

*) Annemette Digmann arbejder som selvstændig aktionsforsker. Cand. Mag. og Ph.d. Har en lang række ansættelser som leder i det offentlige bag sig. Senest 10 år som innovationschef i Region Midtjylland. Har siden 2000 arbejdet som forsker primært med fokus på ledelse. 


\section{A. Indledning}

I SiS nr 5, 2018 bidrog jeg med en artikel om SAMSKABELSE. Baggrunden for artiklen er et fireårigt forskningsprojekt, hvor jeg undersøger, hvordan de kommunale strategier om samskabelse, borgerinvolvering og partnerskaber med borgerne kommer til udtryk i den virkelige verden - i praksis.

Artiklen byggede dels på en analyse af samskabelsescases fra fire kommuner og et hospital; dels på en fortælling om VASKERIET, der er en arbejdsplads og øvebane for udviklingshæmmede. Det bemærkelsesværdige ved Vaskeri-casen var, at de to socialpædagoger, der var igangsættere, havde valgt at sige op og etablere deres eget beskæftigelsestilbud, for ikke bare at kunne lytte til borgerne, men også handle på deres ønsker.

Da Vaskeriet opnåede bemærkelsesværdige resultater, der skabte værdi på adskillige bundlinjer, fik det naturligvis kommunen til at stille spørgsmål som:

- Er det nødvendigt at sige sit job op, for at kunne lytte til - og handle på - borgernes ønsker og behov?

- Hvordan frisætter man en afdeling, så den bliver i stand til at lytte til borgernes ønsker og behov?

Efter at jeg har fulgt arbejdet med samskabelse i et af kommunens botilbud for unge autister i et par måneder i foråret 2019, for at besvare ovennævnte spørgsmål, er min konklusion, at der er mange årsager til, at det er ualmindeligt svært at inddrage borgernes drømme og ønsker i kommunens tilgang til opgaveløsningen.

En af de væsentligste barrierer er formuleret af den tidligere forvaltningschef i kommunen:

"Vi siger, at vi vil have et ultimativt borgerfokus. Men i en stor organisation er der fare for, at vi mister det fokus og får mere blik for os selv og alt det organisatoriske.”

En anden forhindring findes i fagligheden. Lederen udtrykker det således:

"Pædagoger kan godt falde i den grøft, at vi ved hvad der er godt for dig. Det er det, vi er skolet til - at finde vej for andre mennesker."

Her er problemstillingen udtrykt i forhold til pædagogfaget, men udfordringen gælder for alle faggrupper. Når man kender den faglige løsning på borgernes problemer eller ved, hvad det 
kommunale ydelseskatalog kan tilbyde, så er der ingen grund til at spørge, hvad der har betydning for den enkelte borger.

I denne artikel beskriver jeg først de samskabelses-indsatser, der er igangsat på bostedet og derefter, hvilke udfordringer både borgere og medarbejdere oplever, når der skal samskabes i en organisation, der har sat netop det emne på dagsordenen.

Da ingen kan holde til, at svaret er JA til spørgsmålet i artiklens overskrift, afslutter jeg artiklen med en række anbefalinger både til institutioner, der vil udfordre fag-fagligheden og offentlige organisationer, der for alvor ønsker at inddrage borgerperspektivet.

I denne artikel koncentrerer jeg mig om analysen af bostedets forsøg med at samskabe med borgerne, men da jeg samtidig har fulgt andre samskabelsesinitiativer på ældre-, sundheds-, og forebyggelsesområdet, inddrages erfaringerne herfra i delkonklusionerne.

\section{B. Metode og forskningsspørgsmål}

For at blive klogere på, hvordan bostedet kan blive bedre til at understøtte borgerne i at nå deres mål, blev forskningsspørgsmålet formuleret således:

Hvordan kan alle interessenter blive bedre til at samarbejde om, at borgerne bliver i stand til at opfylde deres ønsker og drømme?

\section{Formål}

Med undersøgelsen ønskede vi at skabe viden om, hvordan parterne allerede i dag lykkes med at samarbejde på tværs, for at borgerne kan realisere deres ønsker og drømme - og på hvilke områder parterne kan blive endnu bedre. Der er således lagt op til et aktionsforskningsprojekt, hvor jeg følger og interagerer med den valgte institution eller afdeling, når de øver sig i samskabelse.

Kommunen pegede på, at undersøgelsen kunne foregå på et bosted for autister, der kan bo alene med støtte. Undersøgelsen skal dokumentere, hvordan de forskellige interessenter (pædagoger, pårørende, myndighedsafdeling, administration og borger) lykkes med at samarbejde på tværs af fagligheder og organisatoriske grænser. Der er fokus på at undersøge, hvordan der arbejdes med de perspektiver og ønsker, der er vigtige, for at borgerne får opfyldt deres drømme. Derudover skal undersøgelsen afdække, om der er barrierer eller udfordringer, som de forskellige interessenter oplever på vejen mod, at borgerne kan opfylde deres ønsker og drømme. Endelig 
skal undersøgelsen bidrage med forslag til, hvordan bostedet kan overkomme de oplevede barrierer.

\section{Design}

I forskningsprojektets første fase (dokumentationen) er der blevet gennemført interviews med seks borgere (beboerne på bostedet omtales konsekvent som borgere), otte pårørende (heraf to forældrepar), seks pædagogiske medarbejdere, lederen og tre medarbejdere fra myndighedsafdelingen (en med titel af konsulent og to rådgivere), der alle har tilknytning til bostedets tilbud. Interviewene blev gennemført i perioden mellem 24.april og 6. maj 2019. Efter første udkast til rapporten blev der i slutningen af maj gennemført endnu et interview med lederen. Rapporten blev præsenteret for bostedets ledelse og medarbejdere i juni og for driftsledelsen i august 2019.

Interviewene blev optaget på bånd, bortset fra tre pårørende og en myndighedsperson, der kun havde mulighed for at blive interviewet over telefon. Ved transskribering er der foretaget en meningskondenserende sammenfatning, således at meningen fremskrives og centrale citater, der relaterer sig til undersøgelsens formål, fastholdes.

Herudover ville forskerne observere, hvordan mødet mellem borgere og systemet finder sted. I dataindsamlingsfasen har det kun været muligt at observere et husmøde 2.maj.

Efter dataindsamlingen blev alle interview analyseret efter et display, hvor det blev tydeligt, hvordan de forskellige grupper forholdt sig til forskellige temaer, så som:

- Hvordan lyttes der til borgerne?

- Hvordan læres der på bostedet?

- Hvilke barrierer er der for at lytte og lære på bostedet?

Forskningsrapporten blev udarbejdet i samarbejde med Tine Bieber Lunn fra FACILITATE2EDUCATE.

Aktionsforskningsprojektets anden fase er ikke igangsat, og det er tvivlsomt om det sker. Mere om det afslutningsvis. 


\section{Samskabelse i praksis}

\section{Lyttes der? Læres der?}

På bostedet har lederen valgt metoden 'åben dialog’ som et vigtigt samskabelsesredskab. Metoden tilsiger, at man ikke må tænke i løsninger, men skal finde frem til de forskellige perspektiver, som mødedeltagerne har og være nysgerrige på de forskellige parters perspektiver. Metoden handler om at gå med på borgernes drømme og bidrage til at realisere disse.

Lederen giver desuden udtryk for den grundlæggende værdi, at 'borgerens drømme er det centrale i vores arbejde'. Borgerne skal være herre i eget liv, og det bliver de, hvis medarbejderne er nysgerrige på borgernes drømme og ikke lader egne værdier eller holdninger (eksempelvis om at borgerens drøm er urealistisk) skygge for at lytte til borgerne.

De pædagogiske medarbejdere, der er blevet interviewet, er enige om, at der generelt lyttes til borgerne på institutionen, og at de selv lytter til borgernes ønsker og drømme. Det rummer dog en række dilemmaer, som vi vender tilbage til.

Halvdelen af pædagogerne oplever, at de som faggruppe er blevet bedre til at lytte til borgerne i løbet af de seneste tre år. Det skyldes, at der har været fokus på emnet, og at de på kurser både har fået større forståelse af målgruppen og er blevet introduceret til metoder og redskaber, der fremmer aktiv lytning.

Vi har interviewet seks borgere, der giver udtryk for, at de har mange drømme om eksempelvis:

- at flytte i egen lejlighed,

- at komme på højskole,

- at få en uddannelse, en hund eller blomster i haven,

- at møde drømmeprinsen,

- at få en ledsager med til aktiviteter,

- at kunne invitere de andre til aften hygge/ spil,

- at blive bedre til at cykle,

- at bidrage til at skabe et kulturelt mødested på tværs af handicaps,

- at få plads til at invitere venner og familie til spisning,

- $\quad$ at der er mere fællesskab mellem borgerne på bostedet.

Nogle drømme - som det at få en uddannelse - ligger måske noget ude i fremtiden. Men for at drømmen skal blive til virkelighed, er der ofte nogle konkrete ønsker/behov - som f.eks. at kunne stå op om morgenen - der er en forudsætning for at realisere drømmen. Det er ikke nødvendigvis 
borgerens ønske at komme op om morgenen, og han eller hun opfatter måske heller ikke, at det er et vigtigt skridt for at nå det overordnede mål, men for at realisere den langsigtede drøm må medarbejderen opstille realistiske delmål og motivere borgeren til at tage et skridt ad gangen.

De pårørende oplever alle, at de bliver hørt. Hvis de henvender sig om forhold, der vedrører deres barn/søskende, reageres der hurtigt. Der er stor forskel på, hvor velfungerende borgerne er, og der er en tendens til, at de pårørende (halvdelen), der beskriver deres barn/søskende som velfungerende, er mindst tilfredse. En siger, at de ansatte skal forholde sig til de unge som individer. Der er mange måder at være autist på, og det skal pædagogerne kunne rumme.

Oplever de pårørende, at medarbejderne lytter til borgerne? Det er der ikke enighed om. Mens én giver udtryk for, at der lyttes for meget til borgerens drøm (om f.eks at få kørekort), så har en anden en oplevelse af, at de ansatte ikke bidrager til at realisere borgerens drøm om at få en placering på arbejdsmarkedet.

To pårørende giver udtryk for, at der på nogle områder tales mere end der handles på bostedet. Der er dog enighed om, at medarbejderne på botilbuddet lytter og handler i langt højere grad, end man generelt gør i kommunen. Især udtales der stor kritik af beskæftigelsesområdet, som hverken borgerne eller de pårørende oplever er særligt lyttende eller forstående.

Der har været talt om samskabelse i adskillige år, og der er (mindst) tre perspektiver på emnet:

1. Borgerinvolvering, bruger/borgerinddragelse: Borgerne er medbestemmende aktører.

2. Organisatorisk udvikling: Borgernes stemme og erfaringer bruges som input til udvikling af nye og bedre løsninger.

3. Systeminnovation: Nytænkning sammen med borgerne med et større mulighedsrum af løsninger - også uden for de professionelle systemer.

Den form for borgerinddragelse, jeg møder på bostedet, kan karakteriseres som kategori et, hvor borgeren forsøgsvis inddrages som medbestemmende aktør. Jeg oplever dog, at der hos de forskellige parter er en ambition om at inddrage borgerne mere. Ligeledes er der behov for fortsat at styrke samarbejdet mellem borgere/pårørende og de ansatte. Jeg registrerer endvidere, at der kan opstå uklarhed om, hvem der har ansvar for at handle på borgernes drømme og ønsker. Er det medarbejderen, den pårørende eller borgeren selv?

\section{Anvendte metoder}

Lederen er meget bevidst om, at samskabelse kræver, at der sker en kulturforandring på arbejdspladsen, og at denne skal understøttes af kompetenceudvikling, og han prioriterer, at 
medarbejderne kommer på kurser som eksempelvis 'den motiverende samtale' og 'åben dialog'. Han er lige så optaget af, at den viden, der opnås på kurserne, omsættes til organisatorisk viden, og at der handles på den nye viden. Den vigtigste metode til dette er aktionslæring. Medarbejdere er delt op i teams, og hvert andet teammøde er afsat til aktionslæring.

De metoder, der anvendes for at kunne lytte til borgerne, er især handleplanerne og den åbne dialog. Alle borgere er - ud fra individuel formåen - inddraget i at udarbejde en handleplan, hvori der indgår en række delmål, der løbende drøftes og justeres.

Medarbejderne angiver, at det kan være svært at sætte den nye viden i spil overfor den erfaring (tavs viden), som den enkelte pædagog har opnået. Når man har været vant til hurtigt at komme med forslag eller løsninger på borgernes problemer, så skal der ske en aflæring, inden det bliver muligt for alvor at lytte. Et par medarbejdere angiver, at de har skullet arbejde med at tøjle deres utålmodighed og har skullet øve sig i at blive bedre til at tøve i situationen.

En konsulent fra myndighedsområdet nævner, at åben dialog er en metode, der anvendes i flere og flere sammenhænge. Metoden har bidraget til, at flere medarbejdere er begyndt at lytte til borgerne på en anden måde end tidligere. Hun nævner ligeledes, at det nye set-up med handleplaner skal bidrage til at fremme borgerens ønsker og drømme.

Jeg hører om mange forskellige metoder, men er usikker på, om det er tydeligt for de pædagogiske medarbejdere, at der ganske vist er metodefrihed, men at metoden skal kunne begrundes fagligt. Det er ligeledes uklart, om der er modstrid mellem de forskellige tilgange.

Borgerne er forskellige - og derfor er metoderne det også. Ifølge lederen er det vigtigt at inddrage metoder, der kan komplementere hinanden, for at opnå de opstillede mål.

Både medarbejdere og pårørende fortæller, at der er dilemmaer i at inddrage borgere med autisme i udviklingen af handleplaner, der skal tage udgangspunkt i den enkeltes drøm om fremtiden. For hvad nu hvis man ikke er i stand til at drømme, således at det alligevel er de ansatte, der sætter ord på dét, de mener kunne være drømmen. Hvad nu hvis borgeren eksempelvis ikke drømmer om at flytte, men hvor det er kommunen, der har et ønske om at få frigjort en plads. Om der er metoder til at håndtere disse dilemmaer, vender jeg tilbage til.

Læring og refleksion er sat i system bl.a. ved hjælp af aktionslæring. Der arbejdes desuden på at transformere teoretisk viden til pædagogisk praksis. Der er dog forslag fra nogle medarbejdere om, i højere grad at lade denne praksis udfordre af ' det udefra kommende blik'. Jeg er i tvivl, om den metodiske ramme gælder på alle områder, eller om der er områder, hvor man er fritaget for at 
benytte den? Lederen har tillid til, at medarbejderne agerer på baggrund af de værdier, der skal kendetegne bostedets pædagogik. Om det har konsekvenser, hvis medarbejdere vælger at handle anderledes, hører vi ikke om. Det kan skyldes, at friløb ikke finder sted - eller at der ikke er tid til den fornødne opfølgning.

Jeg er ligeledes i tvivl, om man kan tolke arbejdet med handleplanerne som man vil - eller om der er en standard, som man ikke kan undgå, uden det får konsekvenser.

Endelig er jeg i tvivl, om de mange forskellige tilgange og metoder bliver evalueret? Er der noget, der virker bedre end andet - og er det op til den enkelte medarbejder/team at foretage sin egen evaluering?

Tvivlen er ikke blevet afklaret gennem interview og observationer.

\section{Barrierer og dilemmaer}

Jeg er stødt på forskellige barrierer og dilemmaer, der spænder ben for den samskabelsesvision, der ligger i driftsområdets vision. I det følgende beskrives de tre, som alle parter omtaler.

\section{Barrierer i samarbejdet på tværs af fag og afdelinger}

Det er primært borgerne og deres pårørende, der oplever, at det (manglende) interne samarbejde på tværs af fag og afdelinger spænder ben for at realisere de unges drømme.

Borgerne har den udfordring, at de ikke altid ved, hvem der har den viden, de har brug for, og dermed ikke ved, hvem de skal kontakte. Det er dog særligt de pårørende, der mærker udfordringerne, når samarbejdet på tværs ikke fungerer.

Forældre oplever, at der ingen sammenhæng er mellem den afdeling, der beskæftiger sig med børn med handicap og afdelingen for voksne med handicap. Når barnet bliver 18 år starter kampen forfra.

Herudover er der en barriere i samarbejdet med beskæftigelsesområdet. To pårørende har oplevet, at deres barn er henvist til tilbud, de egentlig er for gode til. Forældrene mener, at borgeren vil kunne klare større opgaver, men oplever ikke, at de bliver lyttet til. I et eksempel undrer det de pårørende, både at den unge ikke får en chance mere, når borgeren tydeligvis har ressourcerne, og at et Værkstedstilbud kan afvise at deltage i et fællesmøde om sagen med henvisning til, at de ikke har tid. 
Andre pårørende har konkrete erfaringer med, at beskæftigelsesafdelingen ikke er i stand til at vurdere borgerens kompetencer og derfor har sendt dem ud til samtaler, hvor de er blevet afvist eller i praktikker, som de har knækket nakken på. Det er ikke kun sket èn, men adskillige gange, hvorefter en af borgerne har konkluderet: 'jeg dur ikke til noget'. Denne borger arbejder nu tre timer om dagen i et job, som hans kontaktpædagog på bostedet har skaffet.

Ingen af poedagogerne giver udtryk for, at de har oplevet udfordringer med andre afdelinger eller forvaltninger, men peger i stedet på udfordringer i samarbejdet med myndighedsfunktionen i deres egen organisation. Selv om der er en bevægelse i holdningerne på tværs, eksisterer der en 'dem og os' kultur. De pædagogiske medarbejdere oplever, at rådgiverne fra myndighedsområdet 'vil se hurtige resultater', mens konsulenterne kan være bekymrede for, om medarbejderne lever op til de faglige standarder, der bør være på et specialiseret botilbud. Særligt to pædagoger giver udtryk for frustrationen over ikke altid at være inddraget i, hvem der tager beslutningerne, og oplever, at kollegaen fra myndighedsområdet bestiller eller efterspørger opgaver, som ikke altid giver mening i den pædagogiske praksis. Et eksempel er, at hvis der for ofte skal evalueres på en handleplan, mister både pædagog og borger ejerskab til planen.

Rådgivere fra myndighedsområdet fortæller, at deres vigtigste opgaver er at sikre fremdrift i handlingsplanen og derefter yde hjælp og rådgivning i forbindelse med konkrete problemstillinger.

Vi hører dog ikke, at pædagogerne overvejer at benytte sig af muligheden for at bestille eller kalde på hjælp fra myndighedsområdet, hvis en sag går i hårdknude.

En repræsentant fra myndighedsområdet giver udtryk for, at der er talt rigtig meget om, hvordan de nye handleplaner skal udspringe af borgerens ønsker og drømme. Det er der ingen, der er i tvivl om at de skal, men alligevel hører konsulenten, at det er en udfordring for nogle pædagogiske medarbejdere at skabe koblinger fra handleplan til praksis. Det undrer konsulenten sig over.

\section{Delkonklusion}

Det er tydeligt, at pædagogerne og de ansatte fra myndighedsområdet ikke i alle tilfælde betragter hinanden som kolleger, der har en fælles sag. To af rådgiverne fremhæver, at de til tider mærker modstand fra pædagogerne, der spørger 'hvorfor kommer I her'? eller bliver mødt med udsagn som, ' du er her ikke til hverdag, og du ved ikke, hvordan det er at være her, når det brænder på'. Det virker ikke som om det lykkes at få de forskellige perspektiver til at berige hinanden. 
Fremadrettet bør der være fokus på, hvordan de forskellige faggrupper får respekt for hinandens perspektiver og dermed bliver i stand til at lære af hinanden til fordel for den fælles opgave.

Ligeledes bør driftsområdet arbejde på at få etableret en dialog med beskæftigelsesområdet, så borgerne hurtigere kan få det rigtige tilbud, uden at skulle igennem adskillige nederlag. Det bliver interessant at følge, om en planlagt omorganisering kan styrke samarbejdet.

Driftsområdet har netop gennemført endnu en ny organisering, således at der ikke længere bør være overgangsproblemer fra ung til voksen. Et nyt center tager sig af mennesker fra 15 - 30 år. Omorganiseringen er endnu så ny, at der ikke er registrerbare resultater. Derfor bliver det spændende at følge, dels hvordan de nye grænser overvindes, dels om det er muligt at forandre en kultur gennem en ny organisering.

Opgaven med at samstemme forskellige faglige perspektiver er et emne, der dukker op i alle de samskabelses-cases, jeg har undersøgt. Hver faggruppe virker til at være overbeviste om, at de løser opgaven på den eneste rigtige måde - og indblanding fra andre faggrupper opleves som irriterende, og ideer og gode råd ignoreres. Det betyder, at de forskellige faglige perspektiver kommer til at modarbejde hinanden. Der er i høj grad behov for at få skabt en kultur, der kan understøtte, at de faglige tilgange kan berige hinanden. Det er langt fra sikkert, at et fag alene kan løse borgernes behov.

\section{Hektisk arbejdskultur som barriere}

Både borgere og pædagoger påpeger, at der på bostedet ofte er en så hektisk hverdagskultur, at det hæmmer evnen til at lytte og er en barriere for samarbejdet. Tre borgere giver udtryk for frustration over at opleve, at deres aftaler aflyses eller simpelthen glemmes. De tolker, at det er travlhed, der gør, at medarbejderne nogle gange glemmer at informere tilstrækkeligt præcist, så der opstår misforståelser og uklarheder, der fylder meget i borgernes hverdag. Flertallet af borgerne efterspørger mere ro og ønsker overblik over, hvem der er ansat, hvem der er på arbejde, og hvem der er vikar. Også medarbejderne påtaler, at der er en udfordring omkring hurtige vagtskift, korte overlap og folk, der kommer og går. Halvdelen af medarbejdere er belastede af dette. Grundfortællingen er, at der er tale om en hektisk kultur hvor man både som medarbejder og borger oplever, at folk har travlt, og at der altid kan bruges flere hænder.

Jeg får en fornemmelse af, at det er vigtigt at demonstrere travlhed for at passe ind i kulturen på stedet. Det bliver i hvert fald bemærket, hvis en medarbejder agerer roligt og tager sig god tid. Når vi spørger, hvad medarbejderne har så travlt med, er svaret, at det er vigtige opgaver: der skal vækkes, der skal handles, hentes medicin, laves mad og klares mange andre nødvendige hverdags aktiviteter. 
Gad vide, om de mange nødvendige gøremål er en forudsætning for, at borgerne kan nå deres mål, eller om travlheden står i vejen for, at borgeren kan nå deres drømme? Gad vide, om det, der viste sig i Vaskeri-eksemplet, nemlig at borgerne kunne løse mange flere opgaver selv, hvis bare de fik lov, også gælder på dette og mange andre bosteder for borgere med handicap?

De ansatte fra myndighedsområdet ser på hverdagen - med en større afstand end pædagogerne. En enkelt har oplevet de hektiske overleveringer ved vagtskifte, men ellers står det lidt uklart for rådgiverne, hvad det pædagogiske personale har så travlt med. Vi ved ikke om de har ret $\mathrm{i}$, at det er kulturen, der er mere hektisk end opgaven kræver, eller om der i højere grad er tale om to faggrupper, der har en manglende forståelse af hinanden både som kolleger og hinandens arbejdsopgaver.

For de pårørende betyder den hektiske arbejdskultur, at der mangler tid til at arbejde med borgernes behov og ønsker. Et eksempel er, at en pårørende oplever, at en borger ikke får nok hjælp til at ændre på sine uhensigtsmæssige vaner, med den begrundelse, at det er der ikke tid til. En anden pårørende oplever at en ressourcestærk borger bliver mere overladt til sig selv end godt er. Den velfungerende borger har også brug for støtte, men den pårørende mener, at det behov overses på grund af tidsmangel.

Medarbejderne giver udtryk for, at den manglende 'sofatid' er en barriere for at få ro på og komme i god dialog med borgerne. Det er en generel oplevelse hos medarbejderne, at de hele tiden skal videre til den næste opgave, også selv om borgeren har brug for at de bliver. På den anden side har den borger, de skal videre til, også behov for, at medarbejderen kommer til aftalt tid.

Der er således et dilemma mellem på den ene side at arbejde i den faste struktur, som medarbejderne har brug for og på den anden side at kunne være fleksibel, når der er behov for det.

\section{Delkonklusion}

Der må på den ene side være et dilemma i at have meget travlt med at gøre det, der står på 'to do listen’ og på den anden side at være tålmodig og træde et skridt tilbage for at lade borgeren selv komme til. I modsætning til medarbejdernes hurtighed, hører vi, at borgerne er langsomme. Det kan tage fire minutter at lukke døren op, eller 10 minutter at hente kaffe. Hvordan skabes der rum til den investering i tid, der skal til for, at borgerne får mulighed for at løse opgaverne selv? Når borgeren selv kan løse enkle opgaver, sker der en tilførsel af ressourcer, som medarbejderne kan bruge på andre opgaver, der måske endda er tættere på den pædagogiske faglighed. 
Man kunne overveje, om de ansatte kunne have en fordel af at øve sig i at være pausestærke og arbejde med at indføre en bevidst tøven i stedet for at levere hurtig handling? Under alle omstændigheder er det vigtigt at få etableret en dialog, om arbejdspladsen har travlt med det rigtige, og hvordan arbejdsdagen bedst kan struktureres.

Borgerne giver udtryk for, at de har behov for en fast struktur og ikke er glade for forandringer. Det kræver orientering i god tid - både til borgerne og de pårørende. Der er ligeledes behov for, at medarbejderne får talt om, hvorvidt det er de rigtige opgaver, der arbejdes med, og at der etableres en bedre dialog med kollegerne fra myndighedsområdet.

Der er travlt alle steder i offentlige virksomheder. Efter at have opholdt mig i en del af dem, får jeg af og til den tanke, om det i alle tilfælde er det rigtige, man har travlt med? Et eksempel er de mange, mange projekter, der ofte er i spil på samme tid. Udviklingsprojekter, hvor nogle af dem handler om det samme, men har forskellige rationaler og tilgange. Det kan være fornuftigt nok, men i så fald skal det kunne forklares - og det er ikke altid tilfældet. Der er behov for, at ledelserne bruger mere tid og flere kræfter på det strategiske ledelsesarbejde - og ikke al deres tid på de driftsnære opgaver. En strategisk ledelsesopgave er således at vurdere, hvor mange udviklingsprojekter organisationen kan rumme og være vedholdende i forhold til de tiltag, der sættes i gang. Desværre er jeg er stødt på flere samskabelsesprojekter, der har mistet ledelsesopmærksomhed undervejs, og som derfor 'sejler' derud af. Ledere kan med fordel gennemgå arbejdspladsens projekt-portefølje for at vurdere, hvilke der skal fortsætte, og hvilke der kan lukkes eller udsættes.

\section{Faglighed som barriere}

Medarbejderne fortæller samstemmende, at deres faglighed er i en positiv udvikling. De mange kurser og nye metoder klæder dem på til at kunne udøve en mere professionel praksis.

På bostedet arbejder man på at finde den bedste tilgang til at arbejde med borgernes ønsker og drømme. Der er blandt medarbejderne en optagethed af at finde ud af, hvordan man bedst muligt spørger, lytter og samskaber med den borger, der er ekspert i eget liv. Den faglige udfordring kan rumme et dilemma mellem borgerens behov for at opnå sin drøm og behovet for hjælp og omsorg.

Dilemmaet opstår, hvis borgeren ønsker at gøre noget, der er uhensigtsmæssigt eller direkte skadeligt for ham eller hende. Det kan være den borger, der gerne vil drikke alkohol, selv om det forværrer vedkommendes sygdom. Borgeren har således modsatrettede ønsker, og det kan sætte pædagogen overfor et dilemma. De fleste pædagoger har oplevet, at borgere kan stå i vejen for deres drømme. En vil gerne rejse, men bruger alle sine penge på få dage; en anden vil gerne tabe 
sig, men spiser chips hver dag; en tredje vil gerne flytte for sig selv, men skal motiveres til at gøre rent og lave mad.

Hvor går grænsen mellem borgernes selvbestemmelse og pædagogens faglige ansvar? Hvordan giver man ansvaret til borgeren, minimerer sit omsorgsgen og giver slip, samtidig med at man har det faglige ansvar?

Den grænse er ikke klar, men må drøftes fra gang til gang. Drøftelserne kan med fordel resultere til spilleregler for, hvordan konkrete dilemmaer håndteres

Medarbejderne er enige om, at deres rolle er at de skal stille sig til rådighed, opstille muligheder, opmuntre og arbejde med borgerens motivation både $\mathrm{i}$ forhold til de nødvendige opgaver $\mathrm{i}$ hverdagen, såvel som i de store drømme for fremtiden. En medarbejder formulerer det tydeligt ved at beskrive sig som borgerens talerør: 'det er altid borgerens ord jeg formidler'.

Alle medarbejdere giver udtryk for, at der er en barriere i at undgå at tage over for borgeren og i stedet være tålmodig og vente på borgerens eget initiativ. I en hektisk hverdag, bliver denne barrierer forstærket. Hovedparten af medarbejderne fortæller, at de arbejder med at lægge hjælperrollen lidt til side. Det er svært, fordi det er en vigtig del af den pædagogiske faglighed. Igen er det en balance, der kræver refleksion.

Der opstår yderligere et dilemma, hvis borgeren ikke ønsker dét, som 'systemet' ønsker. Når kommunen har behov for at få frigjort nogle af de midlertidige boliger, men borgeren ikke ønsker at flytte, er det så pædagogens opgave at motivere til en flytning, selv om det strider mod at følge borgerens umiddelbare ønske?

Endelig er det et dilemma, at netop autister kan have svært ved at forestille sig fremtiden. En medarbejder nævner, at selv om borgeren bidrager med ønsker og drømme til handleplanen, så kan nogle borgere have svært ved at huske eller forstå, hvad de har sagt ja til. To pædagoger nævner, at der er meget oversættelsesarbejde i forbindelse med handleplanerne, og at det ikke kan undgås, at 'der kommer noget af mig med i handleplanen'.

Set udefra opleves medarbejdernes faglighed som meget forskellig. En repræsentant fra myndighedsområdet reflekterer over de mange metoder, der sættes i spil og spørger: 'hvem ved egentlig hvad der virker, tester vi det vi gør?'. Der kan ligge en barriere i, at det er uklart, hvilken faglig tilgang, der er bedst, når man skal arbejde med denne målgruppes ønsker og drømme? 
De pårørende oplever, at fagligheden er i udvikling. Særligt to pårørende fremhæver, at de møder en kompetent viden om autisme og en nysgerrighed hos medarbejderne om at forstå borgerne bedre. Andre stiller spørgsmål ved, om fagligheden bruges optimalt, når det drejer sig om at arbejde konkret med borgernes ønsker og drømme. En enkelt har en oplevelse af, at der tales meget, men handles for lidt. En anden kunne ønske, at medarbejderne var i stand til at se og forstå borgerne endnu mere individuelt.

Lederen giver udtryk for at handleplanen ikke må blive en eksamen, der gennemføres én gang årligt. Handleplanen skal være et aktivt fælles redskab mellem pædagog og borger. Derfor skal den med mellemrum tages op på ugesamtalen. Lederen gør endvidere opmærksom på, at borgerne kan have svært ved selv at handle på målene. Derfor er det vigtigt at tage fat i de handlinger, der er meningsfulde for borgeren. De skal gentages igen og igen, indtil borgeren er i mål.

\section{Delkonklusion}

På bostedet må det være et vigtigt opmærksomhedspunkt at undersøge, om kontakten til og dialogen med de pårørende er, som den skal være. Det, der virker for den ene, er ikke nødvendigvis det bedste for en anden. Både borgere og de pårørende skal i højere grad håndteres individuelt.

Som pædagog kan man ofte opleve, at ligegyldigt hvordan man vælger at handle, så kunne man have gjort noget andet, der måske var lige så effektivt. Det skal man kunne udholde - og en metode til det er at kunne reflektere over dilemmaerne sammen med kollegerne.

På bostedet er der en række dilemmaer, som bedst løses ved, at parterne samtaler sig frem til, hvordan balancen skal være:

- Mellem den myndige borgers selvbestemmelse og den ansattes pædagogiske ansvar

- Mellem borgernes behov for udvikling kontra behovet for omsorg

- Mellem at være hurtig i nogle situationer og langsom i andre

- Mellem at følge et skema eller en 'to do' liste eller at have sofatid og bare være til rådighed for det, der dukker op.

Når man har fundet frem til dét, der kunne være den rigtige balance, er det vigtigt at gennemføre en afprøvning i praksis, inden der konkluderes.

Når jeg analyserer samskabelsescases fra andre kommuner, så er det et gennemgående træk, at det ikke altid giver mening for fagprofessionelle medarbejdere at inddrage borgerne, når man med 
sin faglighed ved, hvad der skal til. Ligeledes opleves det ikke værdiskabende at inddrage andre fagligheder.

Der er behov for, at lederne går foran for at få etableret en kultur, hvor det bliver naturligt at lytte til borgerne og sammen med kolleger reflektere over, hvordan man kan samskabe på tværs af fag og afdelinger.

Når det opleves som en arbejdskrævende opgave ('kamp') for de pårørende, at der ikke er en glidende overgang mellem afdelingen for børn med handicap og afdelingen for unge/voksne med handicap, så bør det være en opgave, som kommunen tager fat i. I den konkrete case hører vi, at der er organisatoriske ændringer på vej, der skal lette overgangen mellem barn og voksenområdet og styrke samarbejdet med beskæftigelsesområdet. Da kultur og vaner sjældent lader sig påvirke af nye streger i et organisationsdiagram, er det vigtigt at følge op på, om ændringerne får betydning i praksis.

\section{Barrierer hos borgere og pårørende}

De pårørende forholder sig lidt mere kritisk end andre til hele visionen om at arbejde med borgernes ønsker og drømme. En pårørende fortæller, at sønnen ikke er i stand til at forestille sig det ukendte. Dét at skulle forestille sig noget ude i fremtiden opleves som endnu et krav, og for mange krav stresser borgeren. For den pårørende er det ikke så vigtigt, at borgeren ikke har en drøm om fremtiden. Det væsentlige er, at han er 'glad og livsduelig'.

Andre pårørende fortæller ligeledes, at borgerne ikke har evner og overblik til at arbejde frem mod mål i fremtiden. Når der er lavet aftale om et mål, oplever de, at medarbejderne siger, hvad borgeren skal gøre, men ikke hjælper dem med at gøre det. Det kan være den borger, der gerne vil tabe sig, men hvor de pårørende ikke oplever, at medarbejderne gør nok for at støtte det projekt. De pårørende ønsker, at medarbejderne tager mere ansvar og i handling hjælper borgeren. Medarbejderne handler ikke, fordi borgeren er myndig og selv skal tage ansvar for målene. De pårørende har det synspunkt, at når der er opsat et mål, som borgeren ikke selv kan realisere, og måske ikke kan se nødvendigheden af, men som er vigtigt for de pårørende (fordi de tænker på borgerens sundhedstilstand), så bør pædagogen træde til og motivere borgeren til at ændre adfærd.

Den pårørende, der ved mest om de anvendte metoder, er meget kritisk over for åben dialog. Et vigtigt element i metoden går ud på, at man mødes ligeværdigt, men 'autisten bliver aldrig ligeværdig med pædagogerne'. Denne pårørende er bekymret for, at metoden, der stammer fra psykiatrien, ikke passer til målgruppen på bostedet, og at man bruger mange ressourcer på at 
indarbejde en metode, som hovedparten af borgerne ikke vil få gavn af. Ifølge denne pårørende er det i orden, at der er nogen, der gerne må vide bedre og tage mere ansvar.

I det første interview med lederen giver denne udtryk for, at den største barriere for at følge borgernes drøm opstår, fordi de ansatte har fokus på den langsigtede udvikling, mens de pårørende er mere optagede af dag til dag udviklingen. I et afsluttende interview fremhæver lederen, at medarbejderne skal balancere mellem lovgivningen, omsorgspligten og den myndige borger. Han har den oplevelse, at anerkendelsen af begrebet om 'den myndige borger' fylder mere hos medarbejderne end de pårørende.

Måske er modsætningen et udtryk for at pårørende og medarbejdere ser forskelligt på medarbejdernes opgaver og faglighed. Hvor medarbejderne gerne vil, at borgerne selv erfarer, hvor langt de kan nå med at opfylde deres drømme og ønsker, så foretrækker en pårørende, at medarbejderne ikke aktivt støtter en borger i noget, der ikke er realistisk. Det modsatte perspektiv hører vi også. Det kan være de pårørende, der har store ambitioner på den unges vegne og gerne vil, at pædagogen bakker op, hvorimod medarbejderen er usikker på, om man så kaster borgeren ud i noget, der kan føre til et nederlag, for 'man vil jo gerne sikre, at det lykkes'.

Spørgsmålet er jo, hvordan parterne på den ene side i fællesskab kan motivere borgerne til at spise mindre, dyrke mere motion, stå op om morgenen og på den anden side kan støtte hinanden i den langsigtede drøm, der kan bestå i, at borgeren får en uddannelse, et arbejde eller bliver i stand til at få sin egen lejlighed.

Da uklarheden om, hvordan parterne bedst samarbejder om at nå borgernes mål, er ressourcekrævende, er det vigtigt, at parterne får gang i dialogen - og i fællesskab evaluerer om eksempelvis 'åben dialog’ er det rette redskab til at realisere borgeres ønsker og drømme.

Selvom både de pårørende og medarbejderne er bevidste om, at borgerne har oplevet nederlag nok, har de forskellige holdninger til, hvordan det undgås i fremtiden. Tre medarbejdere fortæller, at selv om borgerens drøm kan synes meget urealistisk, så er det bedst, at borgeren selv erfarer det. Medarbejderne vil ikke fortælle borgeren, at drømmen er urealistisk, for det er endnu et nederlag. Dette synspunkt bakkes op af et interview med lederen, der siger, 'at borgernes drømme er det centrale i vores arbejde - også selv om vi (som privatpersoner) synes det er urealistisk. Vores udgangspunkt er: 'Hvor starter vi for at komme i mål?'. Vejen til målet indeholder mange delmål, og borgerens mål vil typisk justeres hen ad vejen og blive mere realistisk.'

Selvfølgelig er medarbejderne bevidste om, at borgernes færdigheds niveau kan stå i vejen for drømmen. Som nævnt kan borgeren drømme om en ting og umiddelbart derefter handle på en 
måde, der underminerer drømmen. Borgeren har konfliktende ønsker og behov og kan have svært ved at se det. Endnu et dilemma, som medarbejderne på bostedet skal kunne håndtere.

Rådgiverne fra myndighedsområdet er enige i, at det kan være svært at finde frem til, hvad borgeren ønsker. Jo dårligere fungerende borgeren er, jo sværere bliver det at finde ud af, hvad der vigtigt for ham eller hende. Hvordan samskaber man med borgerne, uden at de ønsker og drømme for fremtiden, man kommer frem til, primært er de pårørendes eller medarbejdernes ønsker?

På trods af dette ønsker især en af rådgiverne, at de pædagogiske medarbejdere får mere lyst og mod til at sætte borgerne fri. De oplever, at medarbejderne i nogen udstrækning bekymrer sig for meget på borgerens vegne.

\section{Delkonklusion}

I samarbejdet mellem pårørende, borgere og medarbejderne kan der opstå dilemmaer og paradokser, der kræver refleksion og dialog. Jeg fornemmer, at man som ansat kan komme i situationer, hvor det er forkert lige gyldigt, hvordan man handler.

På bostedet anvendes aktionslæring som metoden, hvor de forskellige teammedlemmer fremlægger de problemstillinger og dilemmaer, man møder i dagligdagen. Flere af pædagogerne ønsker, dels at metoderne fra aktionslæring udvides til andre møder, dels at man intensiverer aktionslæringen, eksempelvis ved at optage mødet mellem borger og pædagog på video for $\mathrm{i}$ fællesskab at undersøge, hvad der foregår.

Selv om der allerede er plads til refleksion og dialog internt på bostedet, så er der behov for at udvide tilgangen til samarbejdet på tværs af fag og afdelinger, så parterne ikke kommer til at spænde ben for hinanden i bestræbelsen på at realisere borgernes drømme.

\section{E. Konklusion og anbefalinger}

Efter at have opholdt mig i endnu et par kommunale institutioner i foråret 2019 må jeg konkludere, at der stadig er langt fra ord til handling, når det drejer sig om at lytte til og inddrage borgerne i det konkrete borgernære arbejde, men i særdeleshed hvis man for alvor ønsker at gentænke velfærdsydelserne til borgerne sammen med borgerne. Der er mere end nogen sinde brug for at etablere øvebaner for samskabelsestanken. 


\section{Konkrete anbefalinger til bostedet}

Den form for borgerinddragelse, vi møder på bostedet, har jeg valgt at karakterisere som 'den medbestemmende aktør'. Efter at have talt med borgere og pårørende, bliver det tydeligt, at det vil være muligt at gå et skridt videre, således at borgernes erfaringer og ønsker også anvendes til at udvikle bostedet.

Anbefalingerne til bostedet fokuserede på fire områder. Jeg citerer fra rapporten:

\section{"Klarhed}

Da vi ikke kan få øje på, hvem der profiterer af, at der på nogle områder er uklarhed, foreslår vi at:

- Der er behov for, at parterne får klargjort sammenhængen mellem borgerens behov i hverdagen og de langsigtede ønsker og drømme.

- Det bør være tydeligt, hvem der tager ansvar og handler på borgerens ønsker og drømme.

- Det bør være klart for alle, om der er metodefrihed på bostedet - eller om nogle metoder er mere accepterede end andre.

- Der er behov for, at interessenterne undersøger, hvordan deres metoder og viden i højere grad kan bruges i hverdagen og bidrage til at understøtte samarbejdet med borgerne.

\section{Kompetenceudvikling}

Det er vanskeligt at komme fra teori til praksis, men det er nødvendigt at være bevidste om, hvordan pædagogikken kontinuerligt skal udvikle sig, hvis der skal samskabes med borgerne.

- Hvordan opnås større bevidsthed - hos alle - om hvordan teori/metoder overføres til praksis?

- En plan for, hvordan aflæring skal ske, kunne være ønskelig

- Hvordan måler I om (og hvordan) I lykkes? Hvordan fejres det, når I opnår de forandringer, I har stræbt efter som medarbejdere?

- Hvis Aktionslæring er den bedste metode til refleksion og håndtering af dilemmaer, hvordan kan metoden så anvendes mere generelt på bostedet?

- Hvordan kan den viden og de erfaringer, der opnås på , spredes til resten af driftsområdet

\section{Kulturen}

Overalt i den offentlige sektor er der travlt - således også på bostedet. Spørgsmålet er, om I har travlt med de rigtige opgaver? Og på den rigtige måde. Kan en hektisk kultur være direkte kontraproduktiv for opgaveløsningen?

- Hvilke signaler vil I gerne sende til borgerne og dem, der kommer i huset? Er det vigtigt at fortælle hinanden og borgerne, at I har travlt? 
- Hvordan kan I blive bedre til at profitere af, at der kan være forskellige perspektiver på opgaven. Og hvordan vil I få perspektiverne til at gå op i en højere enhed?

- Kunne man forestille sig, at både de pædagogiske medarbejdere og rådgiverne fra Myndighedsområdet lod sig kigge over skulderen?

- Kan andre fagligheder bidrage med nye perspektiver på opgaven? Kan en terapeut noget andet end en pædagog, når det drejer sig om at blive selvhjulpen? Kan det gi mening at få en ekspert i organisering til at give gode råd om arbejdstilrettelæggelsen?

\section{Borgeren i centrum}

Der er en kulturforandring i gang. Den består bl.a. i, at vi ikke længere skal spørge borgerne om, hvad der er i vejen med dem, men i stedet, hvad der har betydning for dem. Det er dog lettere sagt end gjort at gøre sig i stand til at forstå og handle på borgernes ønsker og behov. Men da det er netop dét, samskabelse handler om, så anbefaler vi at bostedet:

- Forsøger med en mere individuel tilgang til den enkelte borger og de pårørende

- Arbejder på i højere grad at frisætte borgerne

- Igangsætter mindre eksperimenter for at blive klogere på, hvad der virker for de forskellige parter."

Da resultaterne af undersøgelsen blev fremlagt for medarbejderne i juni med henblik på at aftale, hvilke aktioner/handlinger, som forskningsprojektet skulle arbejde videre med, bidrog medarbejderne med adskillige forslag til prøvehandlinger. Desværre gik ideerne tabt i den efterfølgende travlhed på bostedet.

Det lykkedes heldigvis at rekonstruere tre handlinger, som bostedet ville arbejde med i august og september 2019. Jeg citerer fra en mail fra lederen af bostedet:

"Vi vil hjælpe hinanden med at undlade at sige, vi har travlt. Alle medarbejdere deltager aktivt i denne prøvehandling.

Vi vil forsøge os med alternative Ugesamtaler. Tre medarbejdere vil hver især afholde Ugesamtaler med de borgere, de har den primære kontakt for, på individuelt tilrettede måder.

Vi vil forsøge at skabe tid til nærvær (Sofatid)."

Om det er lykkedes at gennemføre prøvehandlingerne, og om der er kommet resultater ud af forsøgene, er i skrivende stund uklart. På trods af et par henvendelser er hverken bostedets leder eller driftschefen vendt tilbage. Manglende svar kan jo tolkes på forskellig vis, men på et møde $\mathrm{i}$ slutningen af august med to driftschefer og forvaltningschefen blev det tydeligt for mig, at 
kræfterne aktuelt blev brugt på den større reorganisering af hele forvaltningsområdet. Samtidig er der både kommet en ny forvaltnings- og driftschef til.

Det kunne tyde på, at den tidligere forvaltningschef har ret i antagelsen om, at der (i hvert fald aktuelt) bruges meget mere tid og energi på interne organisatoriske processer end på reel samskabelse med borgerne.

En anden tolkning af den efterfølgende tavshed kan bestå i, at rapportens konklusioner enten ikke er genkendelige eller for voldsomme. Denne tolkning kan dog ikke bekræftes af de møder, der blev afholdt med medarbejdere og ledelse. Tavshed kan være en metode til at negligere, at viden, man ikke ved hvordan man skal håndtere, ikke findes.

Da kommunen har en meget profileret samskabelsesstrategi, vil jeg tillade mig at spørge, om der er tale om en bevidst prioritering af kræfterne - eller om det bare er sådan, man plejer at gøre: altså prioriterer interne processer fremfor samarbejdet med borgerne? En årsag kunne være, at det er det første man bliver målt på. Det kan ligeledes være en udfordring at blive præsenteret for en viden, der udfordrer det glansbillede, kommunen ønsker at skabe om deres evne til samskabelse.

I det aktuelle eksempel er der tale om en politisk ledet, men løst koblet organisation, hvor der er mange forskellige perspektiver i spil. De fagprofessionelle pædagoger, myndighedspersonerne, ledelsessystemet, borgerne og de pårørende lever i forskellige verdner. En årsag kunne være, at det er det første, man bliver målt på. De taler forskellige sprog, og hver gruppe har deres egne succeskriterier, der ikke er samstemte. Gode viljer fra pædagoger og bostedets leder til at lytte og indgå i dialog med borgerne, er langt fra tilstrækkeligt, hvis der skal skabes reel samskabelse. Dertil er systemtænkningen for stærk og den realitet, at processen er standset, kan tolkes således, at definitionsmagten - endnu engang - forblev i det kommunale system.

\section{Generelle anbefalinger}

Stort set alle kommuner har ambitioner om at samskabe med borgere om udvikling af de fremtidige velfærdsløsninger. Men hvis en strategi ikke kan mærkes i handling, vil borgerne opleve, at de bliver reduceret til 'statister i det kommunale samskabelsesteater', som en pårørende formulerer det. Og det holder hurtigt op med at give mening.

I overskriften spørger jeg, om løsningen er, at medarbejderne skal sige deres job op for at være i stand til at lytte til borgerne. Svaret er NEJ - det er selvfølgelig ikke en løsning. I stedet må de offentlige organisationer kontinuerligt udvikle en kultur, hvor det bliver muligt at inddrage borgere som ligeværdige parter. 
I de få eksempler (som jeg har haft adgang til), hvor en kommune er lykkedes med en form for samskabelse, er arbejdet drevet af én leder, der vedholdende har insisteret på, at arbejdspladsen kontinuerligt skal blive klogere på metoder, der kan fremme samskabelse. I alle disse eksempler er ledere rejst til andre arbejdspladser eller er blevet afskediget, uden at tilgangen til samskabelse har nået at blive indlejret i kulturen. Det har betydet, at samskabelsesdagsordenen er gået i stå, blevet sat tilbage - eller i værste fald droppet.

Når de ledere, der for alvor forsøger sig med samskabelse, vælger at forlade deres job eller bliver afskediget, siger det noget om hvor vanskelig og voldsom en kulturforandring, der skal til, hvis samskabelsesdagsorden skal blive reel.

Der er stærke kræfter på spil. I min søgen efter eksempler på samskabelse på velfærdsområderne har jeg talt med flere centralt placerede topembedsmænd. En af dem advarede mig om, at de eksempler ville blive svære at finde, fordi 'det er naivt af dig at tro at vi vil opgive styring og kontrol'.

Mine analyser dokumenterer, at det er svært både for de fagprofessionelle, ledelsessystemet og politikerne at afgive magt til borgerne. De eksempler, der findes, er små og ubetydelige i den store sammenhæng.

Når en kommune skal samskabe med borgerne, er første krav, at man er i stand til at lægge det kommunale og/eller faglige perspektiv til side og for alvor lytte til borgernes ønsker og behov. Det kræver flere ting:

- At den politiske og administrative topledelse for alvor understøtter sagen, sætter den nødvendige ramme, og som rollemodeller går foran.

- At hvert område og hver institution årligt afkræves svar på, hvordan de vil involvere borgere og brugere, og hvad der kommer ud af samskabelsen. Man får det man måler på, og hvis ikke der er incitamenter, der fremmer samskabelse, så sker det ikke.

- Det er nyt at inddrage borgerne, både når der skal udvikles nye løsninger, og når hele systemer skal gentænkes. Det kræver øvelse, og at der bliver plads til at fejle undervejs.

- At man holder fast og er vedholdende, også selv om de første forsøg mislykkes.

- At der afsættes ressourcer til støtte undervejs.

- At man tillader sig at lære af de erfaringer, som eksterne parter (f.eks Vaskeriet) kan bidrage med 
De offentlige organisationer skal igennem en kulturrevolution, hvis det for alvor skal lykkes at inddrage borgernes perspektiver. Det er ikke muligt at gøre, 'som vi plejer'.

Der skal udvikles nye projektmodeller, anderledes tilgange og nye kompetencer. Samtidig skal rammen omkring samskabelse være i orden. Hvis mellemledere og medarbejdere sættes i gang uden investerings-ressourcer eller støtte, så har jeg adskillige eksempler på, at det ender med konflikt og nederlag.

\section{Perspektivering}

Efter at havde fulgt en række eksempler på samskabelse igennem snart fire år, må jeg konkludere, at der er langt igen, inden slagordene bliver til virkelighed. Det er ikke underligt. De offentlige organisationer er alle store fag-bureaukratier, der ofte lever deres eget liv.

Ikke desto mindre er der behov for at fortsætte arbejdet. Ikke kun for at gøre slagord til virkelighed, men også fordi det er nødvendigt at inddrage borgerne i udviklingen af fremtidige velfærdsløsninger.

Desværre hører jeg, at samskabelsesdagsordenen er på vej ud. Slogans holder et par år, og så skal der noget nyt til. Det samme skete med innovationsdagsordenen. Jeg ved ikke, hvordan de næste slagord kommer til at lyde. Men det er sikkert, at ligegyldigt hvilke begreber, der er moderne, så kommer det til at handle om at gentænke velfærdssamfundet, så det bliver bæredygtigt - ikke kun miljømæssigt, men i lige så høj grad økonomisk og socialt. Det kan de offentlige organisationer ikke klare alene. Borgerne skal med fra start. 


\section{Referencer}

Digmann, A. (2019): Innovation finder sted, når grænser krydses. Erhvervspsykologi. Årgang 17, nr. 1.

Digmann, A., Lunn, T.B. (2019): Samskabelse på XX (et bosted for autister). Forskningsrapport afleveret til Bostedet og Kommunen.

Digmann, A. Nielsen, A.M., Ejlersen, L.S. (2018) Dem der siger at det ikke kan lade sig gøre, skal lade vær' med at afbryde os, der allerede er i gang. Samfundslederskab i Skandinavien. Årgang 33, nr. 5, s. 369-393. https://doi.org/10.22439/sis.v33i5.5633

Jørgensen, J.H., Digmann, A., Ingerslev, K. (2016): På Tværs. Grænsekrydsende ledelse og samarbejde. Gyldendal Public.

Nielsen, A.M., Ejlersen, L.S., Digmann, A (2018): Når borgere skaber inkluderende fællesskab. Sager der Samler. Findes på www.sagerdersamler.dk 